\title{
The effect of dietary content of plant protein on the utilization of urea in the bovine rumen
}

\author{
By J. ANNA NIKOLIĆ, M. JOVANOVIĆ, D. STOŠIĆ \\ AND A. PAVLIČEVIĆ \\ Institute for the Application of Nuclear Energy in Agriculture, Veterinary \\ Medicine and Forestry, Zemun/Beograd, Yugoslavia
}

(Received 20 October 1970-Accepted 9 March 197I)

\begin{abstract}
I. Four young Friesian bulls with rumen fistulas were given four isocaloric all-concentrate diets containing different amounts and sources of nitrogen in a Latin square arrangement. Diet HP (high-protein) contained 2.31 \% plant nitrogen; diet MPU (medium-protein with urea) $1.67 \%$ plant nitrogen and $0.69 \%$ urea nitrogen (total $2.36 \%$ ); diet LPU (low-protein with urea) $0.95 \%$ plant nitrogen and $0.69 \%$ urea nitrogen (total $\mathrm{I} \cdot 65 \%$ ); diet HPU (highprotein with urea) $2.28 \%$ plant nitrogen and $0.69 \%$ urea nitrogen (total $2.97 \%$ ), calculated on an air-dry basis.

2. The rumen $\mathrm{pH}$ varied between 5.8 and 6.I with diets $\mathrm{HP}, \mathrm{MPU}$ and HPU, but was significantly lower with diet LPU with values between $5 \cdot 4$ and $5 \cdot 8$.

3. The results showed no differences between the isonitrogenous diets HP and MPU except that replacement of plant nitrogen with urea was followed by an increase in the concentration of ammonia in the rumen. With the diets containing urea, the concentrations of rumen ammonia varied inversely with the amount of dietary plant nitrogen supplied, indicating a negative effect of plant nitrogen on urea utilization.

4. Concentrations of alkali-labile nitrogen (amide) were not increased with diets containing urea except with diet HPU, which produced the highest concentrations of ammonia in the rumen.

5. The concentration of true protein in the rumen and the amino acid distribution were similar with all four diets, indicating the ability of the microflora to adapt to qualitative and quantitative differences in dietary nitrogen intake.

6. Ration acceptability was lower with diets LPU and HPU than with diets HP and MPU.

7. Large differences between individual animals in rumen $\mathrm{pH}$, percentage of dry matter and total nitrogen concentration in the rumen were noted.
\end{abstract}

Nearly 30 years ago Pearson \& Smith (1943) showed how protein synthesis or catabolism may predominate in the rumen digesta according to the conditions present. More recently Chalupa (I968) and Tillman \& Sidhu (I969) have emphasized that a major factor limiting the efficient use of urea nitrogen is the difficulty in obtaining comparable rates of urea hydrolysis and of fixation of the liberated ammonia into microbial protein. Since one mode of ammonia storage in the rumen has been postulated to be as glutamine (Hoshino, Sarumaru \& Morimoto, 1966; Chalupa, Clark, Opliger \& Lavker, I970), it was of interest to discover if amide concentrations in the rumen are raised as a result of feeding with urea and if there is any relationship between the concentrations of amide and ammonia in the rumen. The utilization of non-protein nitrogen for microbial protein synthesis is probably affected by the dietary content of plant protein, digestible carbohydrate and minerals, of which the first is considered in the present paper. An investigation, in which four all-concentrate diets for young growing bulls were used, has been carried out in three parts: (I) an examination of the rumen digesta; (2) measurement of microbial protein synthesis in 
vitro and (3) a feeding experiment under production conditions. The results of the first part are presented here. Observations have been made on rumen $\mathrm{pH}$, ammonia concentration and amino acid content. A brief account of some of these results has been given elsewhere (Nikolić, Jovanović, Stošić \& Pavličević, 1970).

\section{EXPERIMENTAL}

\section{Animals}

Four ro-month-old Friesian bulls with rumen fistulas received $1.5 \mathrm{~kg}$ portions of the experimental diets four times daily and water ad lib. The animals were kept on concrete floors with no bedding.

\section{Diets}

The four diets were designed to contain about $3100 \mathrm{kcal}$ digestible energy $/ \mathrm{kg}$ and were supplemented with equal quantities of minerals and vitamins (Table I). The control diet (HP) contained no urea whereas the other diets all contained $1.5 \%$ crystalline urea in the air-dry feed. Analyses showed that the amounts of total

\section{Table I. Composition and analysis of the experimental diets}

$\begin{array}{cccc}\begin{array}{c}\text { Diet HP } \\ \text { (high- }\end{array} & \begin{array}{c}\text { Diet MPU } \\ \text { (medium- }\end{array} & \begin{array}{c}\text { Diet LPU } \\ \text { (low-protein }\end{array} & \begin{array}{c}\text { Diet HPU } \\ \text { (high-protein }\end{array} \\ \begin{array}{c}\text { protein } \\ \text { diet) }\end{array} & \begin{array}{c}\text { protein diet } \\ \text { with urea) }\end{array} & \begin{array}{c}\text { diet with } \\ \text { urea) }\end{array} & \begin{array}{c}\text { diet with } \\ \text { urea) }\end{array}\end{array}$

$\begin{array}{lcc}\text { Yellow maize meal } & \text { 5I } & 56 \cdot 5 \\ \text { Starch (feed grade) } & - & - \\ \text { Sunflower-oil meal } & \text { I5 } & 3 \\ \text { Sugar-beet pulp (dried) } & 25 & 30 \\ \text { Maize bran } & - & - \\ \text { Dried lucerne meal } & 5 & 5 \\ \text { Urea (feed grade) } & - & \text { I.5 } \\ \text { Mineral and vitamin mixture* } & 4 & 4\end{array}$

$\begin{array}{ll}38 \cdot 5 & 49 \cdot 5 \\ 20 & - \\ 30 & 15 \\ 6 & 25 \\ - & -5 \\ 4 \cdot 5 & 1 \cdot 5 \\ 4 & 4\end{array}$

Analysis (per Ioo g air-dry feed)

\section{Nitrogen (g)}

Ammonia (mg)

Amide $\left(\mathrm{mgNH}_{3}\right)$

Dry matter (g)

$\begin{array}{cc}2 \cdot 31 \pm 0.42 & 2 \cdot 36 \pm 0.12 \\ 24.9 & 20.6 \\ 73 \cdot 1 & 43.4 \\ 85.9 & 85.8\end{array}$

$\begin{array}{cc}I \cdot 64 \pm 0.25 & 2 \cdot 97 \pm 0.32 \\ 25 \cdot 7 & 28.6 \\ 48 \cdot 4 & 73 \cdot 9 \\ 86 \cdot 4 & 85 \cdot 9\end{array}$

* Mineral mixture supplying limestone $(1 \cdot 5 \%), \mathrm{NaCl}(0.5 \%)$, bone meal (Kostan, $1.0 \%)$ which contained $(\mathrm{g} / \mathrm{kg}): \mathrm{Ca}, 320.00 ; \mathrm{P}, 100.00 ; \mathrm{Fe}, 2.45 ; \mathrm{Cu}, 0.25 ; \mathrm{Mn}, 3.00 ; \mathrm{Co}, 0.01 ; \mathrm{I}, 0.02$; and vitamin mixture (Premiks; $1.0 \%$ ) which contained (per kg): vitamin A, 500000 i.u.; cholecalciferol, 80000 i.u.; vitamin $\mathrm{E}, 200 \mathrm{mg}$.

ammonia and alkali labile nitrogen (amide) in the diets were low. The protein equivalents, calculated on an air-dry basis from the total nitrogen content were: diet HP, I $4.4 \%$; diet MPU, $14.7 \%$; diet LPU, $10.3 \%$ and diet HPU, $18.6 \%$, with urea supplying $29 \%, 42 \%$ and $23 \%$ of the total nitrogen in diets MPU, LPU and HPU respectively. At the levels given, diets HP and MPU supplied the daily crude-protein requirement for finishing yearling cattle, diet HPU supplied an excess of crude 
protein, whereas diet LPU contained enough nitrogen only to fulfill the protein requirement for normal growth (National Research Council, 1963). The dietary components were ground through a $5 \mathrm{~mm}$ screen before being mixed thoroughly.

\section{Procedure}

Each diet was given to each young bull for a 5 -week period in a Latin square arrangement. Rumen samples $(300 \mathrm{ml})$ were taken for analysis during the last week of each feeding period. Samples were collected through polyethylene tubing of internal diameter $\mathrm{I} \mathrm{cm}$ into plastic bottles containing $\mathrm{I}^{\circ} 5 \mathrm{~g}$ mercuric chloride as a preservative, in the morning before the first feed and then at $\mathrm{I}, 2,3$ and $5 \mathrm{~h}$ after placing a portion of diet before the animal. The time taken for each animal to consume its portion was noted. The $\mathrm{pH}$ of the rumen contents was measured immediately with a $\mathrm{pH}$ meter (Model 27; Radiometer, Copenhagen). The samples were stored for further analysis at $-13^{\circ}$. All measurements were made on a weight basis and the samples were used unfiltered.

\section{Analyses}

Total nitrogen was determined by the Kjeldahl method on $5 \mathrm{~g}$ samples of the rumen contents and $0.5 \mathrm{~g}$ samples of the diets.

Dry matter was measured after heating $10 \mathrm{~g}$ samples of rumen digesta in an oven at $105^{\circ}$ to constant weight.

Ammonia and amide concentrations were determined in $25 \mathrm{~g}$ diluted rumen contents ( $1: 3$ ) according to the technique of Varner, Bulen, Vanecko \& Burrell (r953), modified as follows. Distillation was carried out for 15 min periods under reduced pressure at a water-bath temperature of $80^{\circ}$ for ammonia and $98-100^{\circ}$ for amides. The distillate was collected into $100 \mathrm{ml} \mathrm{I} \%(\mathrm{w} / \mathrm{v})$ boric acid. The recoveries and standard errors of single determinations based on forty-one measurements of a mixture of ro $\mathrm{ml} 0.005 \mathrm{M}$-ammonium sulphate solution and $\mathrm{r} 0 \mathrm{ml} \mathrm{O} .0 \mathrm{r} \mathrm{M}$-asparagine solution were found to be $97^{\cdot} \cdot \pm 4 \cdot 0 \%$ and $91^{1} \cdot 2 \pm 6 \cdot 8 \%$ respectively. Under the conditions used for amide determination the recovery from $10 \mathrm{ml} 0.005 \mathrm{M}$-urea solution was $5.4 \%$.

For amino acid determinations, $10 \mathrm{~g}$ rumen samples were hydrolysed in $100 \mathrm{ml} 6 \mathrm{M}$ hydrochloric acid for $22 \mathrm{~h}$ at $110^{\circ}$ in an open reflux system, filtered and evaporated nearly to dryness under reduced pressure at $40^{\circ}$. The samples were dissolved in citrate buffer ( $\mathrm{pH} 2 \cdot 2)$, filtered and adjusted to a predetermined volume before analysis on the amino acid analyser (Model I20B; Beckman Instruments Inc., Palo Alto, California). Careful adjustment of the buffer eluants permitted separation of methionine from $\alpha, \epsilon$-diaminopimelic acid.

Statistical analyses were made according to Snedecor (1956) on an IBM Computer.

\section{RESULTS}

\section{Conditions in the rumen}

Rumen $p H$. The changes in the $\mathrm{pH}$ of the rumen contents up to $5 \mathrm{~h}$ after the animals began to eat are shown in Fig. $\mathrm{I}$; the $\mathrm{pH}$ fell to a minimum at $2-3 \mathrm{~h}$. No significant differences were observed between diets HP, MPU and HPU, but the 
$\mathrm{pH}$ after a feed of diet LPU, which contained the low level of nitrogen, was significantly lower $(P<0.05)$ except at 5 h.

Nitrogen concentration. The concentration of total nitrogen in rumen contents was significantly greater $(P<0.05)$ with diet HPU than with each of the other diets (Fig. 2), whereas no significant differences were detected among the other diets. A similar picture occurred when the results were expressed in relation to the dry

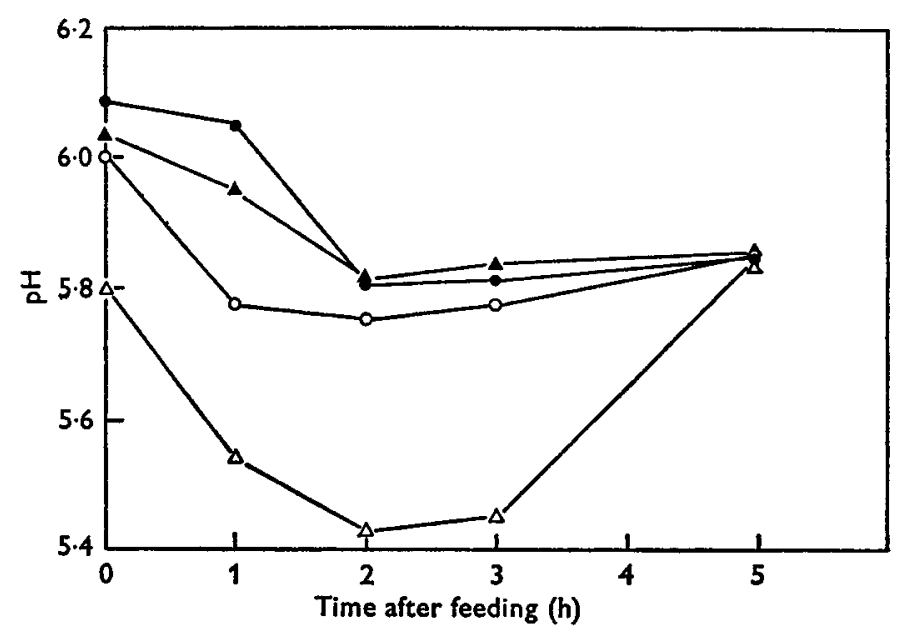

Fig. I. Mean values for rumen $\mathrm{pH}$ of four young bulls in relation to time after beginning to feed on different diets. $\mathrm{O}-\mathrm{O}$, high-protein diet (HP); $-\mathbf{O}$, medium-protein diet with urea (MPU); $\triangle-\Delta$, low-protein diet with urea (LPU); $\Delta-\Delta$, high-protein diet with urea (HPU).

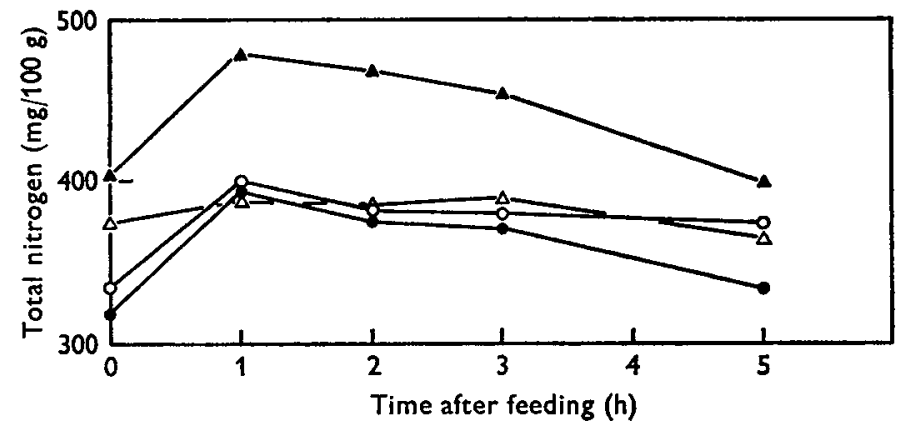

Fig. 2. Mean values for total nitrogen concentrations in rumen contents of four young bulls in relation to time after beginning to feed on different diets. $\mathrm{O}-\mathrm{O}$, high-protein diet (HP); -1 medium-protein diet with urea (MPU); $\triangle-\Delta$, low-protein diet with urea (LPU); $\Lambda-\Lambda$, high-protein diet with urea (HPU).

rumen contents. With diet HPU the concentration of nitrogen was mainly between $5 \%$ and $6 \%$ of the dry matter, which is significantly larger than for diet LPU $(4-5 \%)$. The nitrogen concentrations with the isonitrogenous diets HP and MPU were very similar and between the extremes found with diets LPU and HPU. Thus the total nitrogen content of the dry matter in the rumen appeared to depend on the dietary intake to a certain extent (Fig. 3). 
Ammonia concentration. Large differences in the levels of free volatile bases, calculated as ammonia, in the rumen contents were found with the four diets (Fig. 4). When diets containing urea (MPU, LPU and HPU) were given, sharp peaks in ammonia concentration occurred $\mathrm{I} h$ after feeding. The height of these peaks increased

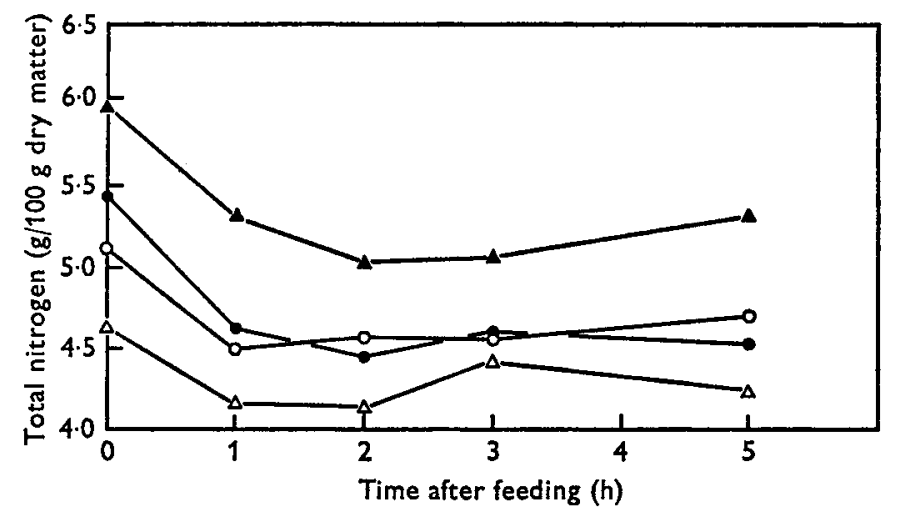

Fig. 3. Mean values for total nitrogen concentrations in dry rumen digesta of four young bulls in relation to time after beginning to feed on different diets. $\mathrm{O}-\mathrm{O}$, high-protein diet (HP); $\longrightarrow$, medium-protein diet with urea (MPU); $\triangle-\Delta$, low-protein diet with urea (LPU); $\Delta-\mathbf{\Delta}$, high-protein diet with urea (HPU).

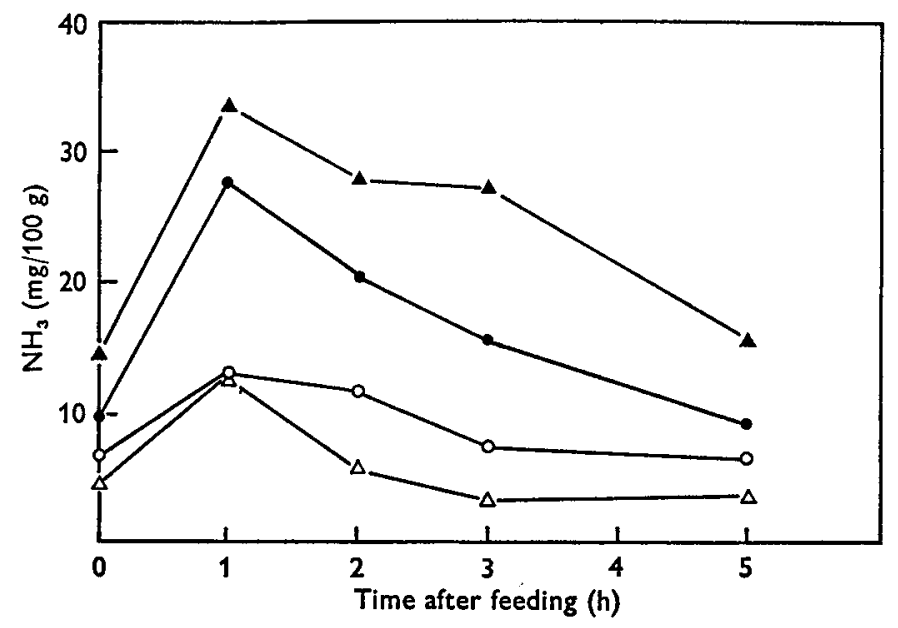

Fig. 4. Mean values for ammonia concentrations in rumen contents of four young bulls in relation to time after beginning to feed on different diets. $\mathrm{O}-\mathrm{O}$, high-protein diet (HP); -1 , medium-protein diet with urea (MPU); $\triangle-\triangle$, low-protein diet with urea (LPU); $\Delta-\mathbf{A}$, high-protein diet with urea (HPU).

as the dietary content of plant protein nitrogen was raised. The rounded curve that occurred with diet HP was much lower than that with the isonitrogenous diet MPU. The mean values for ammonia concentration in rumen digesta were $8.9 \mathrm{mg}, 16.4 \mathrm{mg}$, $5.9 \mathrm{mg}$ and $23.8 \mathrm{mg} \mathrm{NH}_{3}$ per $100 \mathrm{~g}$ digesta with diets HP, MPU, LPU and HPU respectively. Only the difference between diets HP and LPU was not statistically significant. 
Amide concentrations. There were no significant differences between diets HP, MPU and LPU (Fig. 5), but the amide concentration in rumen contents was greater with diet HPU $(P<0.05)$. Since this difference was still apparent when the amide nitrogen was calculated as a percentage of total nitrogen, a greater proportion of amide groups occurred only when dietary nitrogen was supplied at a high level.

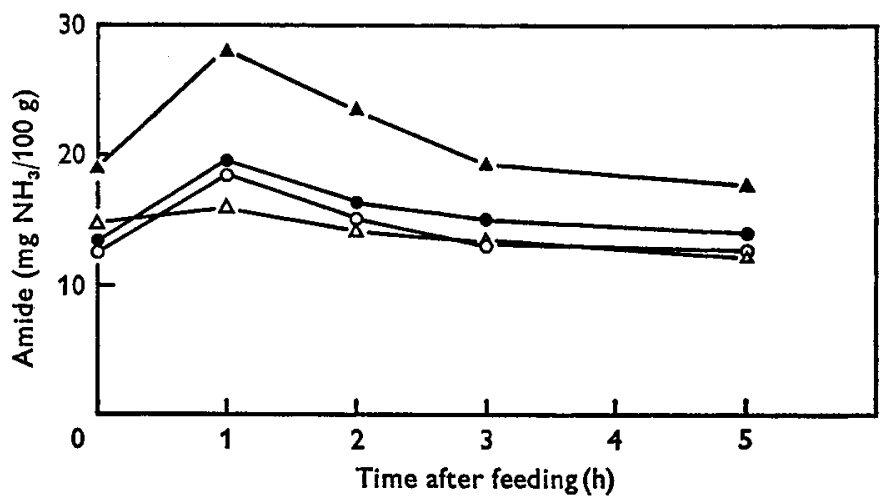

Fig. 5. Mean values for labile amide groups in the rumen digesta of four young bulls in relation to time after beginning to feed on different diets. $\mathrm{O}-\mathrm{O}$, high-protein diet (HP);

- medium-protein diet with urea (MPU); $\triangle-\triangle$, low-protein diet with urea (LPU);

$\Delta-\mathbf{A}$, high-protein diet with urea (HPU).

Table 2. Amino acid composition of hydrolysates of rumen contents from young bulls 3 h after feeding

(Mean values and standard deviations expressed as $\mathrm{g}$ residue/ $100 \mathrm{~g}$ amino acid residues recovered)

\begin{tabular}{|c|c|c|c|c|}
\hline Amino acid & $\begin{array}{l}\text { Diet HP } \\
\text { (high- } \\
\text { protein) }\end{array}$ & $\begin{array}{c}\text { Diet MPU } \\
\text { (medium-protein } \\
+ \text { urea) }\end{array}$ & $\begin{array}{l}\text { Diet LPU } \\
\text { (low protein } \\
\text { + urea) }\end{array}$ & $\begin{array}{l}\text { Diet HPU } \\
\text { (high-protein } \\
+ \text { urea) }\end{array}$ \\
\hline Lysine & $7.89 \pm 0.53$ & $8 \cdot 22 \pm 0.97$ & $7 \cdot 80 \pm I \cdot 51$ & $7 \cdot 69 \pm x \cdot 38$ \\
\hline Histidine & $2.47 \pm 0.28$ & $2 \cdot 46 \pm 0.29$ & $2 \cdot 42 \pm 0.22$ & $2.25 \pm 0.24$ \\
\hline Arginine & $5 \cdot 54 \pm 1 \cdot 02$ & $5 \cdot 16 \pm 0.26$ & $5.54 \pm 0.34$ & $5.53 \pm 0.60$ \\
\hline Aspartic acid & I I. $20 \pm 0.32$ & I I $67 \pm 0.20$ & II.09 II. I 5 & $\mathrm{II} \cdot 74 \pm \mathrm{I} \cdot \mathrm{I} 8$ \\
\hline Threonine & $5.20 \pm 0.10$ & $5.41 \pm 0.23$ & $5.89 \pm 0.73$ & $5.3^{8} \pm 0.27$ \\
\hline Serine & $4.76 \pm 0.34$ & $4.78 \pm 0.20$ & $5.48 \pm 0.76$ & $4.80 \pm 0.21$ \\
\hline Glutamic acid & $15.98 \pm 0.78$ & I $5.54 \pm 0.73$ & $16 \cdot 10 \pm 1 \cdot 69$ & $16 \cdot 38 \pm 0.69$ \\
\hline Proline & $4.20 \pm 0.40$ & $4.19 \pm 0.29$ & $4.10 \pm 0.62$ & $4.05 \pm 0.53$ \\
\hline Glycine & $4 \cdot 88 \pm 0.10$ & $4.76 \pm 0.20$ & $4.78 \pm 0.16$ & $4.79 \pm 0.16$ \\
\hline Alanine & $6.28 \pm 0.29$ & $6.30 \pm 0.56$ & $6.74 \pm 0.11$ & $6 \cdot 28 \pm 0.38$ \\
\hline Cystine & $x \cdot 34 \pm 0.45$ & I. $14 \pm 0.20$ & $0.68 \pm 0.23$ & I·I I \pm 0.77 \\
\hline Valine & $5 \cdot 78 \pm 0.21$ & $5.62 \pm 0.6 I$ & $5.71 \pm 0.21$ & $5^{\prime 7} 79 \pm 0.32$ \\
\hline Methionine & $x \cdot 38 \pm 0.69$ & $I \cdot 4 I \pm 0.48$ & $I \cdot I_{5} \pm 0.46$ & $0.99 \pm 0.72$ \\
\hline Isoleucine & $4.89 \pm 0.9 \mathrm{I}$ & $5.08 \pm 0.38$ & $4.78 \pm 0.34$ & $4.98 \pm 0.36$ \\
\hline Leucine & $8.89 \pm 0.42$ & $8.99 \pm 0.69$ & $8 \cdot 46 \pm I \cdot 14$ & $8 \cdot 88 \pm 0.27$ \\
\hline Tyrosine & $3 \cdot 80 \pm 1 \cdot 03$ & $3.71 \pm 0.94$ & $4.25 \pm 0.92$ & $3.93 \pm 0.62$ \\
\hline Phenylalanine & $5.54 \pm 0.18$ & $5 \cdot 58 \pm 0.88$ & $5.00 \pm 0.97$ & $5.40 \pm 0.53$ \\
\hline
\end{tabular}

Amino acid distribution. The distribution of amino acids in the rumen contents $3 \mathrm{~h}$ after feeding is shown in Table 2. The similarity of the results with the various diets was striking. The proportions of some essential amino acids, such as phenylalanine, leucine, isoleucine and the sulphur acids, tended to be very slightly lower and those 
of non-essential amino acids, such as tyrosine, serine and alanine, to be slightly higher with diet LPU, but these differences were not significant. Tryptophan was not determined but the content of $\alpha, \epsilon$-diaminopimelic acid, a constituent of the cell wall of many bacteria (Work, 195I; Rhuland, r960), was estimated in the last three feeding

\section{Table 3. Distribution of nitrogen in the rumen contents of young bulls 3 h after feeding}

(Mean and standard deviations for four animals, expressed as $\mathrm{mg} \mathrm{N} / 100 \mathrm{~g}$ dry matter)

$\begin{array}{lccccc} & \begin{array}{c}\text { Diet HP } \\ \text { (high- } \\ \text { protein) }\end{array} & \begin{array}{c}\text { Diet MPU } \\ \text { (medium- } \\ \text { protein } \\ \text { +urea) }\end{array} & \begin{array}{c}\text { Diet LPU } \\ \text { (low-protein } \\ \text { +urea) }\end{array} & \begin{array}{c}\text { Diet HPU } \\ \text { (high-protein } \\ + \text { urea) }\end{array} & F \\ \text { Ammonia N } & 81 \pm 56 & 147 \pm 62 & 29 \pm 14 & 291 \pm 138 & 7 \cdot 57^{*} \\ \text { Amide N } & 130 \pm 10 & 146 \pm 19 & 127 \pm 23 & 172 \pm 50 & 1 \cdot 53 \\ \text { Amino acid N } & 2903 \pm 263 & 2888 \pm 227 & 2830 \pm 568 & 2862 \pm 240 & 0.75 \\ \text { Total N } & 4530 \pm 405 & 4560 \pm 483 & 4410 \pm 994 & 5060 \pm 888 & 0.45 \\ & * \text { Significant at the } 0.05 \text { level of probability. } & & \end{array}$

Table 4. Statistical analysis of the components of variance (mean square) for the analytical results

\begin{tabular}{|c|c|c|c|c|c|c|}
\hline \multirow[b]{2}{*}{ Measurement } & \multirow{2}{*}{$\begin{array}{l}\text { Source of } \\
\text { variation }\end{array}$} & \multicolumn{5}{|c|}{ Time after feeding (h) } \\
\hline & & 0 & I & 2 & 3 & 5 \\
\hline $\mathrm{pH}$ & $\begin{array}{l}\text { Sampling period } \\
\text { Animals } \\
\text { Treatments } \\
\text { Error }\end{array}$ & $\begin{array}{l}0.123 \\
0.063 \\
0.064 \\
0.180\end{array}$ & $\begin{array}{l}0.198 \\
0.749 \\
0.202 \\
0.087\end{array}$ & $\begin{array}{l}0.154 \\
0.849 \\
0.133 \\
0.065\end{array}$ & $\begin{array}{l}0.132 \\
0.719 \\
0.131 \\
0.095\end{array}$ & $\begin{array}{l}0.118 \\
0.581 \\
0.000 \\
0.149\end{array}$ \\
\hline $\begin{array}{l}\text { Dry matter } \\
(\mathrm{g} / \mathrm{I} 00 \mathrm{~g})\end{array}$ & $\begin{array}{l}\text { Sampling period } \\
\text { Animals } \\
\text { Treatments } \\
\text { Error }\end{array}$ & $\begin{array}{r}4 \cdot 45 \\
15 \cdot 35 \\
3 \cdot 39 \\
4 \cdot 62\end{array}$ & $\begin{array}{r}0.34 \\
18.32 \\
0.95 \\
7.09\end{array}$ & $\begin{array}{r}0.75 \\
21 \cdot 13 \\
1 \cdot 29 \\
6 \cdot 25\end{array}$ & $\begin{array}{r}0.21 \\
19.20 \\
0.75 \\
6.66\end{array}$ & $\begin{array}{r}0.42 \\
16 \cdot 49 \\
I \cdot 07 \\
4 \cdot 04\end{array}$ \\
\hline $\begin{array}{l}\text { Total } \\
\text { nitrogen } \\
\text { (mg/roo g } \\
\text { rumen } \\
\text { contents) }\end{array}$ & $\begin{array}{l}\text { Sampling period } \\
\text { Animals } \\
\text { Treatments } \\
\text { Error }\end{array}$ & $\begin{array}{r}9600 \\
37020 \\
6100 \\
3730\end{array}$ & $\begin{array}{r}3040 \\
57500 \\
7530 \\
5120\end{array}$ & $\begin{array}{r}4870 \\
5^{6} 320 \\
7590 \\
5270\end{array}$ & $\begin{array}{r}4650 \\
55070 \\
5890 \\
5660\end{array}$ & $\begin{array}{r}9090 \\
32160 \\
2980 \\
4480\end{array}$ \\
\hline $\begin{array}{l}\text { Ammonia } \\
\text { (mg NH} \\
\text { I oo g rumen } \\
\text { contents) }\end{array}$ & $\begin{array}{l}\text { Sampling period } \\
\text { Animals } \\
\text { Treatments } \\
\text { Error }\end{array}$ & $\begin{array}{r}17 \cdot 1 \\
9 \cdot 4 \\
73 \cdot 3 \\
31 \cdot 8\end{array}$ & $\begin{array}{r}62 \cdot 6 \\
6 \cdot 4 \\
566 \cdot 4 \\
166 \cdot 9\end{array}$ & $\begin{array}{r}60.3 \\
28.9 \\
390.9 \\
119.7\end{array}$ & $\begin{array}{r}17 \cdot 8 \\
11 \cdot 4 \\
454 \cdot 8 \\
57 \cdot 7\end{array}$ & $\begin{array}{r}19 \cdot 7 \\
7 \cdot 7 \\
105 \cdot 9 \\
36 \cdot 4\end{array}$ \\
\hline $\begin{array}{l}\text { Amide } \\
\text { (mg NH} \\
\text { Ioo g rumen } \\
\text { contents) }\end{array}$ & $\begin{array}{l}\text { Sampling period } \\
\text { Animals } \\
\text { Treatments } \\
\text { Error }\end{array}$ & $\begin{array}{r}5 \cdot 6 \\
84 \cdot 2 \\
107 \cdot 9 \\
13 \cdot 7\end{array}$ & $\begin{array}{r}6 \cdot 2 \\
146 \cdot 0 \\
74 \cdot 3 \\
30 \cdot 0\end{array}$ & $\begin{array}{r}4 \cdot 3 \\
28 \cdot 9 \\
34 \cdot 4 \\
20 \cdot 2\end{array}$ & $\begin{array}{r}7 \cdot 8 \\
86 \cdot 7 \\
34 \cdot 8 \\
50 \cdot 3\end{array}$ & $\begin{array}{r}5 \cdot 9 \\
38 \cdot 9 \\
28 \cdot 7 \\
14 \cdot 4\end{array}$ \\
\hline
\end{tabular}

periods. This acid occurred at concentrations of $0.20 \pm 0.03 \mathrm{~g}, 0.23 \pm 0.12 \mathrm{~g}$, $0.40 \pm 0.13 \mathrm{~g}$ and $0.26 \pm 0.14 \mathrm{~g}$ per $100 \mathrm{~g}$ dry rumen contents with diets HP, MPU, LPU and HPU respectively. The total amount of amino acid nitrogen per roo $\mathrm{g}$ rumen dry matter was closely similar with all diets (Table 3). The factors for converting amino acid nitrogen (excluding tryptophan) into protein were calculated to be 6.39 , $6 \cdot 36,6 \cdot 3$ I and $6 \cdot 36$ respectively for diets HP, MPU, LPU and HPU. 


\section{Animal variation}

Analysis of variance of the $\mathrm{pH}$ values showed that the greatest component was provided by individual differences between the animals (Table 4 ). Thus animals nos. 3 and 4 had rumen $\mathrm{pH}$ values significantly higher than animals nos. I and $2(P<0.05)$. The same animals had lower concentrations of dry matter and total nitrogen in the rumen contents $(P<0.05)$ and consumed their rations more quickly. However, there were no significant differences between the cattle in total nitrogen content, when calculated as a percentage of dry rumen contents (Fig. 6), or in the concentrations of rumen ammonia. This indicates that the individual variations arose from differences among the animals in factors, such as rate of salivary secretion, water consumption and rate of outflow from the rumen, that were not studied in these investigations.

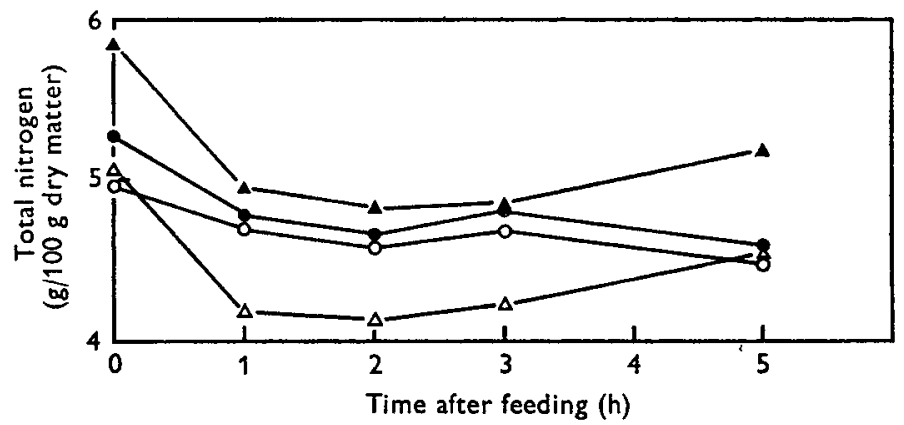

Fig. 6. Mean values for total nitrogen concentrations in dry rumen digesta of four young bulls in relation to time after beginning to feed on the same diets. $\mathrm{O}-\mathrm{O}$, animal no. $\mathrm{I}$; animal no. $2 ; \Delta-\Delta$, animal no. $3 ; \Delta-\Delta$, animal no. 4 .

\section{Health of the animals}

The cattle were healthy throughout the experiment except for the occasional occurrence of frothy bloat, particularly with diet LPU; this did not happen in the feeding experiment under production conditions (Part 3 ) when the animals had access to maize stalks. Nevertheless, the cattle generally consumed their rations readily; thus portions of diets HP and MPU were eaten in a mean time of $\mathrm{I}$ I min after being placed before the animal, which indicates that replacement of most of the dietary sunflower meal by maize and urea in the latter diet had no effect on the palatability of the ration. The rates of consumption of diets LPU and HPU, in which the nitrogen contents were different, were slower ( $26 \mathrm{~min}$ and $17 \mathrm{~min}$ respectively). All the animals chewed the wood of their pens.

\section{DISCUSSION}

Many factors control the rumen $\mathrm{pH}$, but the values are generally low when allconcentrate diets are given. This appears to be partly due to the higher concentrations of volatile fatty acids (Storry \& Rook, I966; Emmanuel, Lawlor \& McAleese, 1969; Whitelaw, Hyldgaard-Jensen, Reid \& Kay, 1970) and the lower rates of salivary flow 
(Oltjen, Putnam \& Davis, 1965; Lawlor, Giesecke \& Walser-Kärst, I966; Putnam, Yarns \& Davis, 1966 ) that occur with such diets. Generally a low $\mathrm{pH}$ is associated with a reduction or complete absence of rumen protozoa which, by rapid ingestion of starch, provide a further buffer against changes in the environment (Purser \& Moir, 1959; Eadie, Hyldgaard-Jensen, Mann, Reid \& Whitelaw, 1970). Although no conclusions as to the dominant factor operating in this investigation can be made because salivary flow rate, volatile fatty acid concentrations and protozoal numbers were not determined, it can be suggested that feeding with diet LPU led to lowered numbers of protozoa and, from the increase found in the concentrations of diaminopimelic acid, raised numbers of bacteria. However, since diaminopimelic acid was not determined during the first feeding period, the statistical benefit of a Latin square arrangement was not applicable here and the difference was not statistically significant. Moreover the use of the concentration of diaminopimelic acid as an indicator of bacterial numbers has been criticized, but nevertheless it does indicate a tendency in a particular direction (Virtanen, 1967).

The amino acid distribution in the whole rumen contents in this investigation approximates more closely to the results obtained for rumen bacteria by Purser \& Buechler (1966) and Bergen, Purser \& Cline (1968) than for those for protozoa, indicating that bacteria form a predominant part of the rumen digesta $3 \mathrm{~h}$ after feeding. The proportion of methionine was lower than that found by these authors and was nearer to the value for rumen total proteins reported by Virtanen (1967), who also successfully separated diaminopimelic acid from the methionine peak. Nevertheless the presence of undegraded dietary proteins is suggested by the high proportion of glutamic acid, which constitutes a considerable fraction of the total amino acids in both sunflower-oil meal and maize meal (Stošić \& Čuperlović, 1967). Zein, in particular, has been reported to be slowly degraded in the rumen (Lewis, 1961).

A striking fact to emerge from these studies is the closely similar amount of amino acid nitrogen that occurred with each of the four diets (Table 3). Thus, although the increased intake of dietary nitrogen with diet HPU, led to a greater concentration of nitrogen in the rumen, the concentration of true protein was not affected by either the qualitative or quantitative changes in food nitrogen sources. The proportion of amino acid nitrogen was less than that reported for separated rumen bacteria by Purser \& Buechler (1966) but greater than the values given by Richardson \& Tsien (1963) for strained rumen fluid. This similarity in concentration and quality of rumen protein is probably responsible for the failure to observe any differences in growth rate and carcass quality when these four diets were used under production conditions (Sevkovic, Stošić, Rajić, Zotović \& Bezbradica, 1970). It can thus be concluded that $10.3 \%$ crude protein, of which $42 \%$ is supplied as urea, is sufficient for beef cattle when given in a high-energy ration. The successful utilization of such a diet by ruminants is partly due to the metabolic recycling of urea which has been found with diets of low nitrogen content (Gray, Pilgrim \& Weller, 1958; Packett \& Groves, 1965 ). The rate of absorption of ammonia through the rumen wall depends largely on its concentration and the $\mathrm{pH}$ in the rumen (Chalupa, 1968). A balance between this loss and the return of nitrogen to the rumen, as salivary urea for example, has been postulated to occur at about $7 \mathrm{mg}$ 
of ammonia nitrogen per $100 \mathrm{ml}$ rumen contents (Waldo, 1968). In this investigation values were generally near or below this figure for diets HP and LPU but above it with diets MPU and HPU. A net loss of food nitrogen as ammonia from the rumen and eventually as urea in the urine may thus be assumed to occur with the latter two diets. Loss of nitrogen in the urine is an important factor in urea feeding (Lewis, I96r ; Hembry, Pfander \& Preston, 1969).

Since urease activity in the rumen is invariably very high (Caffrey, Hatfield, Norton \& Garrigus, 1967; Pearson \& Smith, I943; Jones, MacLeod \& Blackwood, 1964), rumen ammonia concentration can be taken as a reflection of the protein synthesis activity of the rumen microflora when the level of urea feeding and the rumen $\mathrm{pH}$ are the same. Thus the addition of urea to diet HP (diet HPU) leads to an almost triple increase in the mean value for rumen ammonia concentration. When the level of plant nitrogen is reduced (diet MPU) the value falls to a level which is still nearly double that of the isonitrogenous diet HP. With diet LPU, however, the low value indicates that the synthetic activity of the bacteria is commensurate with the rate of release of ammonia from urea with this diet. Djordjević, Jovanović, Stošić, Nikolić \& Jovančević (1970), using $\mathrm{Na}_{2}{ }^{35} \mathrm{SO}_{4}$ have shown a greater incorporation of radioactivity into rumen protein in vitro with diet LPU than with diets HPU and MPU, which supports the above postulate. Owen (1967) proposed that diets must contain less than $12 \%$ protein nitrogen for efficient use of urea supplements.

The similarities in the concentrations of primary amide nitrogen with the various diets show that urea feeding per se does not lead to changes. Only when rumen concentrations of ammonia are high is nitrogen present as amide in an increased amount. The $30 \%$ of rumen nitrogen uncharacterized (Table 3 ) may occur largely as nucleic acids, and compounds such as purines and nitrates. This fraction is being further investigated.

The authors wish to acknowledge the financial support of the Federal Fund for Scientific Work, SFR Yugoslavia and the Republic Fund for Scientific Work, SR Serbia. We would like to thank Dr R. Andrić for performing the fistulation operations, Mrs M. Cuperlović for assistance with the amino acid analyses, Mrs D. Djordjević and Miss M. Urošević for technical help and Mr R. Milošević for care of the cattle.

\section{REFERENCES}

Bergen, W. G., Purser, D. B. \& Cline, J. H. (1968). F. Dairy Sci. 51, 1698.

Caffrey, P. J., Hatfield, E. E., Norton, H. W. \& Garrigus, U. S. (1967). F. Anim. Sci. $26,595$.

Chalupa, W. (rg68). F. Anim. Sci. 27, 207.

Chalupa, W., Clark, J., Opliger, P. \& Lavker, R. (1970). F. Nutr. Ioo, r6r.

Djordjević, D., Jovanović, M. Stošić, D., Nikolić, D. \& Jovančević, V. (1970). Proceedings of the First Yugoslav International Conference of Animal Production p. 302. Novi Sad, Yugoslavia: štamparski pogon SNP-a.

Eadie, J. M., Hyldgaard-Jensen, J., Mann, S. O., Reid, R. S. \& Whitelaw, F. G. (1970). Br. F. Nutr. 24, 157 .

Emmanuel, B., Lawlor, M. J. \& McAleese, D. M. (1969). Br. F. Nutr. 23, 805.

Gray, F. V., Pilgrim, A. F. \& Weller, R. A. (1958). Br. F. Nutr. 12, 413.

Hembry, F. G., Pfander, W. H. \& Preston, R. L. (1969). Fedn Proc. Fedn Am. Socs exp. Biol. $28,492$.

Hoshino. S., Sarumaru, K. \& Morimoto, K. (I966). F. Dairy Sci. 49, 1523. 
Jones, G. A., MacLeod, R. A. \& Blackwood, A. C. (ı 964). Can. F. Microbiol, 10, 37 I.

Lawlor, M. J., Giesecke, D. \& Walser-Kärst, K. (1966). Br. F. Nutr. 20, 373.

Lewis, D. (I96I). In Digestive Physiology and Nutrition of the Ruminant p. 127 [D. Lewis, editor]. London: Butterworths.

National Research Council (1963). Nutrient Requirements of Domestic Animals. No. 4. Nutrient Requirements of Beef Cattle. Washington, D.C. : National Academy of Sciences-National Research Council.

Nikolić, J. A., Jovanović, M., Stošić, D. \& Pavličević, A. (1970). Proceedings of the First Yugoslav International Conference of Animal Production p. 303. Novi Sad, Yugoslavia: štamparski pogon SNP-a.

Oltjen, R. R., Putnam, P. A. \& Davis, R. E. (1965). F. Anim. Sci. 24, I 126.

Owen, E. C. (1967). In Urea as a Protein Supplement p. 329 [M. H. Briggs, editor]. Oxford: Pergamon.

Packett, L. V. \& Groves, T. D. D. (1965). F. Anim. Sci. 24, 341.

Pearson, R. H. \& Smith, J. A. B. (1943). Biochem. F. 37, 148.

Purser, D. B. \& Buechler, S. M. (r966). F. Dairy Sci. 49, 81.

Purser, D. B. \& Moir, R. J. (1959). Aust. F. agric. Res. ro, 555.

Putnam, P. A., Yarns, D. A. \& Davis, R. E. (1966). Y. Anim. Sci. 25, I 176.

Richardson, D. \& Tsien, W. S. (1963). F. Anim. Sci. 22, 230.

Rhuland, L. E. (1960). Nature, Lond. 185, 224.

Sevković, N., Stošić, D., Rajić, I., Zotović, M. \& Bezbradica, Lj. (1970). Proceedings of the First Yugoslav International Conference of Animal Production p. 300. Novi Sad, Yugoslavia: štamparski pogon SNP-a.

Snedecor, G. W. (1956). Statistical Methods 5 th ed. Ames, Iowa: Iowa State University Press.

Storry, J. E. \& Rook, J. A. F. (1966). Br. F. Nutr. 20, 217.

Stošić, D. \& Cuperlović, M. (1967). Savremena Poljoprivreda 15, 197.

Tillman, A. D. \& Sidhu, K. S. (1969). F. Anim. Sci. 28, 689.

Varner, J. E., Bulen, W. A., Vanecko, S. \& Burrell, R. C. (1953). Analyt. Chem. 25, I528.

Virtanen, A. I. (I967). In Urea as a Protein Supplement p. I85 [M. H. Briggs, editor]. Oxford: Pergamon.

Waldo, D. R. (1968). f. Dairy Sci. 51, 265.

Whitelaw, F. G., Hyldgaard-Jensen, J., Reid, R. S. \& Kay, M. G. (1970). Br. F. Nutr. 24, I 79.

Work, E. (1951). Biochem. F. 49, 17. 